GLOBAL JOURNAL OF MEDICAL SCIENCES VOL. 7 NO. 1 \& 22008 : 43 - 50

COPYRIGHTৎ BACHUDO SCIENCE CO. LTD PRINTED IN NIGERIA. ISSN 1596 - 2911

\title{
INCIDENCE OF PES PLANUS AMONGST THE PEOPLE OF CROSS RIVER STATE
}

\author{
M. A. ELUWA, R. B. OMINI, A. O. AKPANTAH AND T. B. EKANEM \\ (Received 28 February, 2007; Revision Accepted 7 April, 2008)
}

\begin{abstract}
The incidence of Pes planus was determined among the people of Cross River State. A total of 1000 individuals comprising 500 males and 500 females of Cross River State origin and aged 20-30 years were used to assess the prevalence of Pes planus. All volunteers involved in the study had no deformities or previous fractures of the lower extremities especially of the foot. For each volunteer, bilateral plantar prints were obtained using ink procedure method. All prints were counted, separated into sexes and the incidence of flat foot calculated for both sexes. A total of 111 individuals had flat foot comprising 44 males and 67 females. The overall incidence of Pes planus was $22.20 \%$ with a prevalence of $8.80 \%$ amongst males and $13.40 \%$ amongst females. Bilateral flat foot was more common in females $(11.20 \%)$ than in males $(6.00 \%)$. Unilateral flat foot was more common in males $(2.80 \%)$ than in females $(2.20 \%)$. Our result shows that the prevalence of flat foot is higher amongst the females than the males in Cross River State with the prevalence being $22.20 \%$.
\end{abstract}

KEYWORDS: Pes planus, males, females, Cross River State

\section{INTRODUCTION}

Humans have bipedal postures, more specifically, they stand and walk with erect trunk and knees. Moreover, they are plantigrades, setting the whole length of the foot down on the ground, whereas most medium to large mammals which are digitigrades and ungulates stand on the hooves on the tip of their toes (Gray, 2005). The foot acts as a pliable platform to support the body forward in walking, running or jumping. To meet these requirements, the human foot is designed in arched form with tendons and muscles to hold it in position (Chaurasia, 2004).

Pes planus commonly called flat foot is a deformity of the foot marked by loss of arches of the foot especially the medial longitudinal arch. With this condition, on standing the medial border of the foot almost touches the ground. Other anatomical

M. A. Eluwa, Department of Anatomy, Faculty of Basic Medical Sciences, University of Calabar, P. M. B. 1115, Calabar, Nigeria.

R. B. Omini, Department of Anatomy, Faculty of Basic Medical Sciences, University of Calabar, P. M. B. 1115, Calabar, Nigeria.

A. O. Akpantah, Department of Anatomy, Faculty of Basic Medical Sciences, University of Calabar, P. M. B. 1115, Calabar, Nigeria.

T. B. Ekanem, Department of Anatomy, Faculty of Basic Medical Sciences, University of Calabar, P. M. B. 1115, Calabar, Nigeria. 
abnormalities may be associated e.g. valgus of the heel, abduction at the mid-tarsal joint etc. (Canale, 1998). Pes planus may be unilateral or bilateral indicating bone and joint pathology (Hunter, 2002). It may be congenital or acquired (Chaurasia, 2004). The 'acquired' means that some physiological or structural changes cause deformity in a foot that was structurally normal. Insufficiency or dysfunction of the posterior tibial tendon has been thought of as the most common cause of acquired adult flat foot abnormality. Recent researches have focused more on the static restraints of the medial longitudinal arch. The spring ligament, plantar fascia and the deltoid ligament may contribute to the development of a fallen longitudinal arch (Deland, 2001). The incidence of posterior tibial tendon pathology or rupture is higher in the middleaged women with co-existing obesity as documented by some authors (Funk et. al., 1986, Johnson, 1983, Mann and Thompson, 1985, Myerson, 1993).

Flat foot is a common in infants and toddlers due to their thick subcutaneous fat in the sole of the feet. In adulthood, the arches have developed (Moore and Dalley, 1999, Chen, 2004). The arches appear when the individual stands erect. Painful flat feet may be associated with other conditions and require attention (Chen, 2004). People with flat foot can walk as comfortable as others with normal feet as long as there is no heel cord contracture which may limit function (Staheli et. al., 1987). The presence of flat foot is known to prevent successful athletic competition but they are more liable than normal feet to suffer foot strain (Apley and Solomon, 1990). And there is an increased tendency of injury to occur which may worsen the condition (Lifield, 1991, Galick and Webb, 1990). Flat feet indirectly possess a problem on normal gait and less frequently diagnosed in Nigeria. This study was therefore carried out to provide a data on the prevalence of flat foot amongst the people of Cross River State.

\section{MATERIALS AND METHODS}

A total of one thousand individuals aged between 20-30 years of Cross River State origin drawn from the University of Calabar community and its environs volunteered for the study. This was made up of 500 females and 500 males of Cross River State origin (fathers and mothers are from Cross River State). All volunteers involved in this study had no previous deformities or fractures of the lower extremities especially of the foot. For each volunteer, bilateral plantar prints were obtained using the ink procedure method (Antonuck, 1975). Endorsing ink were applied to the already cleaned soles and individual made to stand on a plain duplicating paper. The outline of the foot was drawn with a pencil. The procedure was repeated for the second foot. Contact index II (the ratio of the contact width to the total width of the foot) was used to classify the feet. This index correlates with contact index I (ratio of contact area to the total area of the middle of the foot). The procedure is as stated below (See fig. 1 and 2).

From the outline of the foot, the midpoint of the margin of the heel mark I was connected by lines $1 \mathrm{~A}$ and $1 \mathrm{~B}$ to the distal portion of the big toe ' $A$ ' and second toe 'B'. Transverse lines $C D$ and EF were drawn to divide the feet into anterior $3 / 10$ and 4/10. Another line $\mathrm{GH}$ at the middle was drawn to divide the feet into two equal halves. On the medial border, a line 


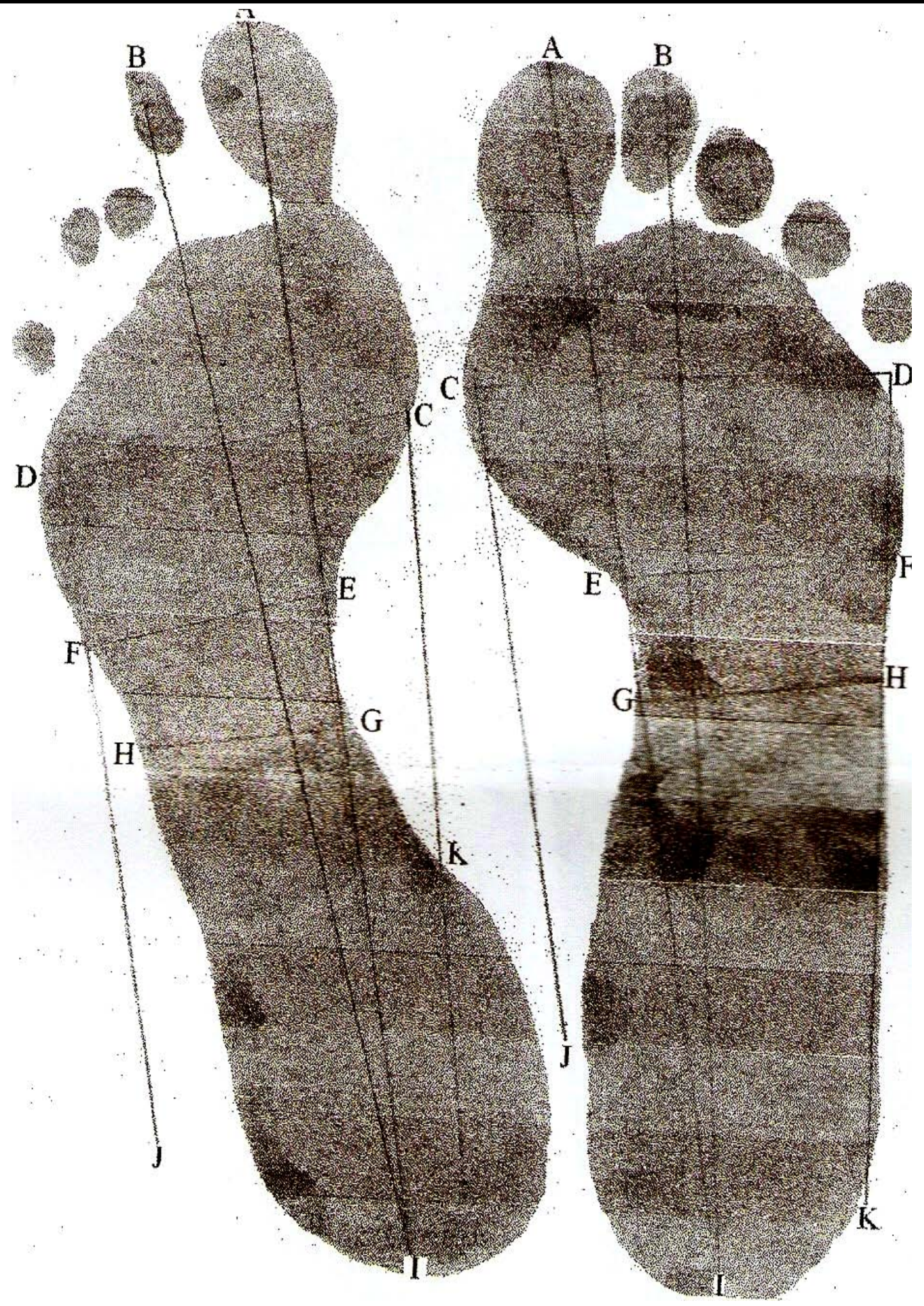

Fig 1: Foot prints of normal feet 


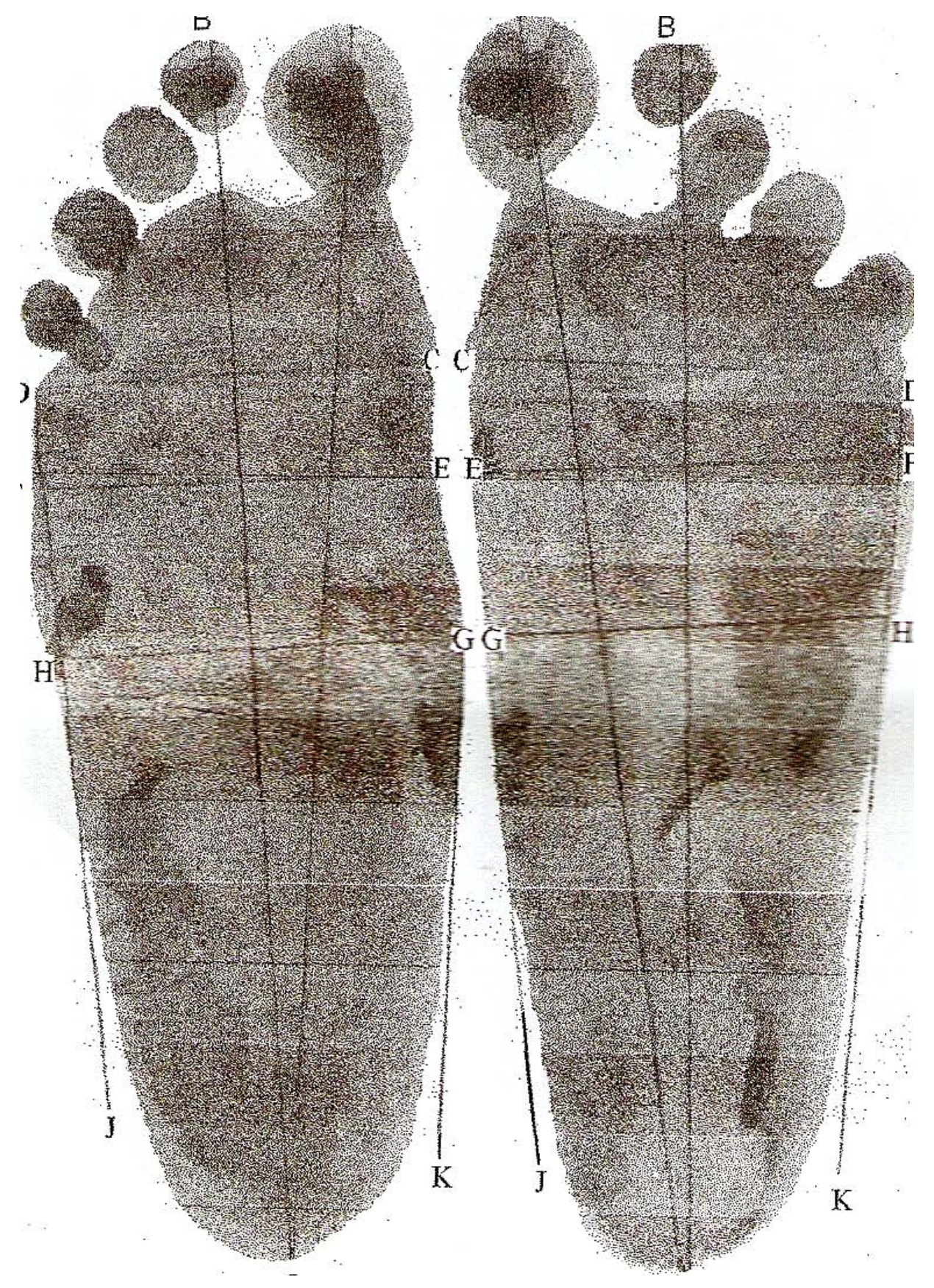

Fig 2: Foot prints of bilateral flat feet 


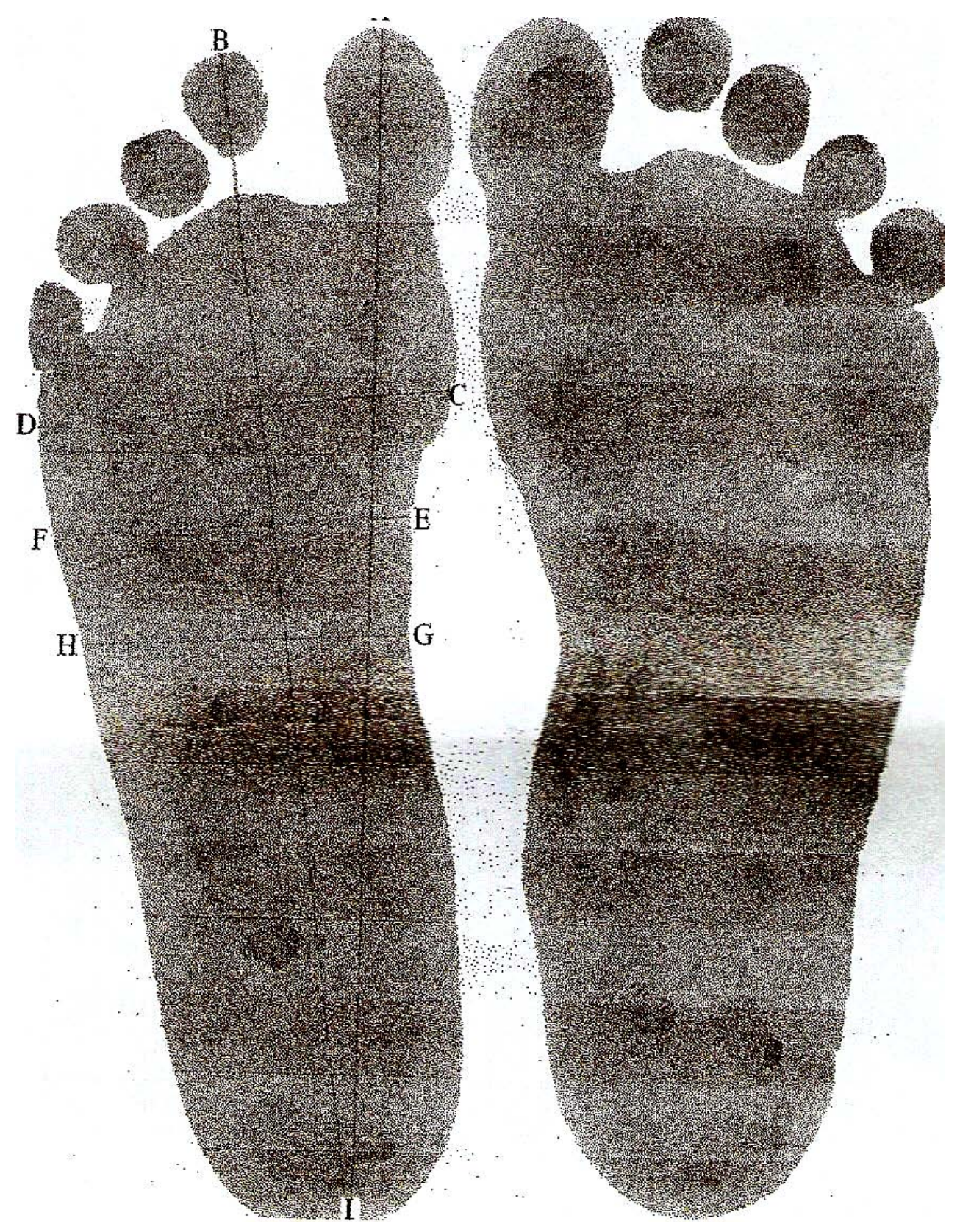

Fig 3: Foot prints of unilateral flat foot

CJ was drawn from the head of the first metatarsal, C to the heel J. Another one, DK from the head of the $5^{\text {th }}$ metatarsal laterally joined the heel. Contact index II was calculated. Mean values $\pm S D$ of 1 was regarded as normal but more or less than this was regarded as abnormal (flat foot). 


\section{RESULTS}

Table 1: Mean contact index for females and male subjects (normal feet)

\begin{tabular}{|c|c|c|c|}
\hline \multirow{2}{*}{ Sex } & No. of volunteers & \multicolumn{2}{|c|}{ Mean contact index II } \\
\cline { 3 - 4 } & & Right & Left \\
\hline Females & 500 & $0.50 \pm 0.08$ & $0.52 \pm 0.07$ \\
\hline Males & 500 & $0.62 \pm 0.01$ & $0.63 \pm 0.01$ \\
\hline
\end{tabular}

Table 2: Mean contact index for females and male subjects (flat feet)

\begin{tabular}{|c|c|c|c|}
\hline \multirow{2}{*}{ Sex } & No. of volunteers & \multicolumn{2}{|c|}{ Mean contact index II } \\
\cline { 3 - 4 } & & Right & Left \\
\hline Females & 500 & $0.655 \pm 0.161$ & $0.550 \pm 0.151$ \\
\hline Males & 500 & $0.514 \pm 0.220$ & $0.556 \pm 0.151$ \\
\hline
\end{tabular}

Peak values for normal feet were 0.650 for males and 0.54 for females, while those of flat feet were 0.95 for males and 0.73 for females.

Table 3: Incidence of unilateral flat foot among subjects

\begin{tabular}{|c|c|c|c|c|c|}
\hline Sex & $\begin{array}{c}\text { No. of } \\
\text { volunteers }\end{array}$ & Normal feet & flat feet & Total & $\begin{array}{c}\text { Percentage } \\
\text { Incidence }\end{array}$ \\
\hline Females & 500 & 433 & 11 & 444 & $2.2 \%$ \\
\hline Males & 500 & 456 & 14 & 470 & $2.8 \%$ \\
\hline
\end{tabular}

Table 4: Incidence of bilateral flat feet among subjects

\begin{tabular}{|c|c|c|c|c|c|}
\hline Sex & $\begin{array}{c}\text { No. of } \\
\text { volunteers }\end{array}$ & Normal feet & flat feet & total & $\begin{array}{c}\text { Percentage } \\
\text { Incidence }\end{array}$ \\
\hline Females & 500 & 433 & 56 & 489 & $11.2 \%$ \\
\hline Males & 500 & 456 & 30 & 486 & $6.0 \%$ \\
\hline
\end{tabular}

Out of a total of one thousand volunteers from the University of Calabar community and its environs, one hundred and eleven (111) were flat footed, forty-four were males and sixty-seven females. The overall prevalence was $22.20 \%$. The prevalence of Pes planus amongst males was $8.80 \%$ while that for the female was $13.40 \%$. Bilateral Pes planus was higher in females $(11.20 \%)$ than the males $(6.00 \%)$. The unilateral Pes planus was higher in males $2.80 \%$ than in females $2.20 \%$.

\section{DISCUSSION}

Pes planus is usually classified as flexible or rigid. Flexible Pes planus is common, 15 to $20 \%$ of adult population has some degree of flexible Pes planus and most of these are asymptomatic (Canale, 1998). Soft tissue structural changes are the cause of flexible Pes planus whereas, it is bony and soft tissue changes that cause a rigid Pes planus foot. It is possible to clinically distinguish the two types of Pes planus- if an 
acceptable medial longitudinal arch develops on non weight-bearing, then flat foot is considered rigid (Canale, 1995). Most of these factors do not apply to the subjects of this study who are young adults, with no obvious deformities. The presence of flat foot observed in this study may be due to congenital factors. The individuals may have slight bony mal-arrangement or laxity of muscles or aponeurosis of the plantar surface of the foot. Long flexure tendons like flexor hallucis longus may not be effective enough for maintenance of the arch.

The prevalence was found to be higher in females than in males. This may be due to the fact that females tend to have smaller bones and less bulky muscles. Since both factors help in the maintenance of the arches of the foot (Hicks, 1955), females are therefore, more prone to developing Pes planus. A research carried out by Didia and Asomugha (2004) on the incidence of flat foot amongst the athletes in Port Harcourt showed that the incidence of unilateral flat foot was higher in female athletes $(4 \%)$ than in males $(3 \%)$. The result of this study is also in line with the result carried out by Igbigbi and Mpango (1998) on the prevalence of Pes planus amongst students in Mbarara University of Science and Technology, Uganda. The prevalence amongst the males was $3.11 \%$ while that for females was $6.67 \%$. The overall prevalence was found to be $9.88 \%$. The prevalence of Pes planus in Nigeria compared to other African countries is (111 per 1,000 of the population). Kenyans have 432 per 1,000 of the population, the highest ever documented and twice as high as Tanzanians (203 per 1,000 of the population) (Igbigbi et. al., 2005).

It has been shown that in adult, flat feet are often free of symptoms but they are more liable to suffer feet strains (Apley and Solomon, 1990). They are also prone in later life to osteoarthritis of the tarsal joints consequent upon their mal-alignment (Apley and Solomon, 1990). The fact that the subjects are young adults without any apparent deformities tends to support the above assertion. This study has provided a reference data on the incidence of Pes planus in Cross River State.

\section{REFERENCES}

Antonuk, S. A., 1975. The method of receiving human palmar prints. Voprosy Anthropology ; 50: 219-221.

Apley, A. G. and Solomon, L., 1990. Apley's systems of orthopaedics and fracture, pp. 310-311, London, Butterworth and Company (Publishers) Ltd.

Canale, S T., 1998. Campbell's Operative Orthopaedics (vol. 2) Mosby, St. Loius, 1712.

Chaurasia, B. D., 2004. Human Anatomy. Regional and Applied. Dissection and Clinical. Volume 2. Lower Limb, Abdomen and Pelvis. Fourth edition. CBS publishers and Distributors. P.162.

Chen, A. L., 2004. Pes Planovalgus; Flat feet. American Accreditation Healthcare Commission (www.urac.org).

Deland, J. T. (2001). The adult acquired flat foot and spring ligament complex. Pathology and implication for treatment. Foot An Mar, 6(1): 129135, vii (medline)

Didia, B. C. and Asomugha, A. L., 2004. The incidence of flat foot among adults in Port Harcourt. J Expt Clin Anat, 3(2): 58-59.

Funk, D. A., Cass, J. R. and Johnson, K. A. 1986. Acquired adult flat foot secondary to posterior tibial tendon pathology. $J$ Bone Joint Surg Jan, 68(1): 95-102 (medline).

Garick, J. G. and Webb, D. R., 1990. Sport injuries diagnose and management. Philadelphia. W. B. Saunders. Pp. 261, 265: 292-296. 
Gray, H., 2005. Gray's Anatomy. The anatomical basis of clinical practice. $39^{\text {th }}$ edition. Elsevier Churchill Livingstone, pp. 1534-1535.

Hicks, J. H., 1955. The foot as a support. Acta Anatomica, 25: 34-35.

Hunter, G., 2002. Pes Planus (Flat Foot). Discussion paper prepared for the workplace safety and insurance appeals tribunal. Adobe web site.

Igbigbi, P. S. and Mpango, L., 1998. Prevalence of Pes planus amongst the students in Mbarara University of Science and Technology, Uganda. West Africa. Journal of Anatomy: vol. 6. Pp. 25-27.

Igbigbi, P. S., Msamati, B. C. and Sheriff, M. B., 2005. Arch index as a predictor of Pes Planus. J Am Podiatr Med Assoc; 95(3): 273-276.

Johnson, K. A., 1983. Tibialis posterior tendon rupture. Clin Orthop, Jul-, Aug, 177-140-7 (medline).
Lifield, P. W., 1944. Pes planus: Military significance and treatment with simple arch support. J. A. M. A. 124: 281-283.

Mann, R. A., Thompson, F. M., 1985. Rupture of the posterior tibial tendon causing flat foot. Surgical treatment. J Bone Joint Surg, 67(4); 556-561 (medline).

Merriman, L. M. and Tollafield, D. R., 1985. Assessment of the Lower Limb. Churchill Livingstone, New York.

Moore, K. L. and Dalley, A. F., 1999. Clinically Oriented Anatomy. $4^{\text {th }}$ edition, Lippincort Williams and Wilkins, pp. 642-643.

Myerson, M. S., 1993. Adult acquired flat foot in adult due to dysfunction of the posterior tibial tendon. Instr Course Lec, 393-405 (medline).

Steheli, L., Chew, D. and Gorbeth, M., 1987. The longitudinal arch. A survey of eight hundred and eighty feet in normal children and adults. $J$ Bone Joint Surg, 69A: 426-428. 